DOI: $10.25095 /$ mufad.881460

\title{
Stoklara İlişkin Hükümlerin KÜMİ FRS Kapsamında İncelenmesi ve Türkiye'deki Mevcut Uygulama ve Standartların Karşılaştırılması*
}

\author{
Yusuf KAYA** \\ Mehmet UTKU***
}

\section{ÖZET}

12.07.2019 tarihinde yayınlanarak kamuoyu görüşüne sunulan Küçük ve Mikro Işsletmeler İçin Finansal Raporlama Standardı (KÜMI FRS) Taslağl, toplam 22 bölüm ve 105 sayfadan oluşmaktadır. Standardın uygulamaya başlanmasıyla birlikte, küçük ve mikro ölçekli işletmelerde de vergi temelli muhasebe yaklaşımından bilgi temelli muhasebe yaklaşımına geçilecektir. Uygulayacak işletme sayısı bakımından geniş kapsamlı olması sebebiyle KÜMI FRS'nin anlaşılabilirliği büyük önem taşımaktadır. Bu çalışmayla amaçlanan, işletme varlıkları içinde büyük paya sahip olan stoklar grubunun, KÜMI FRS hükümleri çerçevesinde ele alınması ve VUK/MSUGT, TMS 2 Stoklar ve BOBI FRS Stoklar bölümüyle karşılaştırılarak muhasebeleştirme işlemlerinin nasıl yapılacağının gösterilmesidir. KÜMİ FRS stoklar bölümü incelendiğinde, TMS/TFRS ve BOBI FRS'ye göre daha az detaya yer verildiği görülmektedir. Bu sayede stoklara ilişkin hükümler daha anlaşılabilir ve daha kolay uygulanabilir hale gelmiştir. KÜMI FRS stokların satın alınmasında vade farkının ayrıştırılması ve stoklarda değer düşüklüğü gibi konularda diğer standartlardan ayrlmaktadır. VUK/MSUGT'a göre ise birçok konuda benzerlik gösterse de dönüştürme maliyetleri, hizmet işletmelerinde stok maliyeti, maliyet ölçüm teknikleri, gibi konularda yenilikler getirmiştir.

Anahtar Kelimeler: Stoklar, KÜMI FRS, BOBİ FRS, TMS 2.

JEL Sinıflandirması: M40, M41, M48.

\section{Analysis of Inventory Provisions within the Scope of SME FRS and Comparison of} Current Practices and Standards in Turkey

\section{ABSTRACT}

The Financial Reporting Standards for Small and Micro Enterprises (SME FRS), which were published on 12.07.2019 and presented to the public, consists of 22 chapters and 105 pages in total. With the implementation of the standard, small and micro-size enterprises will switch from tax-based accounting approach to knowledge-based accounting. Understandability of SME FRS is of great importance since it is comprehensive in terms of the number of businesses to be implemented. The aim of this study is to handle the inventories, which has a large share in the business assets, within the framework of the provisions of SME FRS and to show how the accounting transactions will be made by comparing them with GCASA, TAS 2 Inventories and LMSE FRS Inventories. When the SME FRS inventories section is examined, it is seen that less details are included than TAS / TFRS and LMSE FRS. In this way, the provisions regarding the inventories became more understandable and easier to apply. KUMI FRS differs from other standards in terms of separation of late interest and depreciation in inventories. According to the GCASA provisions, although they are similar in many aspects, it has brought innovations in subjects such as conversion costs, inventory cost in service businesses, cost measurement techniques.

Keywords: Inventories, SME FRS, LMSE FRS, TAS 2.

Jel Classification: M40, M41, M48.

\footnotetext{
* Makale Gönderim Tarihi: 16.02.2021, Makale Kabul Tarihi: 20.06.2021 , Makale Türü: Nitel Araştırma

** Dr.Öğr.Üyesi, Pamukkale Üniversitesi, Buldan Meslek Yüksekokulu, ykaya@pau.edu.tr, ORCID: 0000-00022076-9808.

*** Dr.Öğr.Üyesi Pamukkale Üniversitesi, İktisadi ve İdari Bilimler Fakültesi, mutku@pau.edu.tr, ORCID: 00000002-7076-6891.
} 


\section{GíRiş̧}

Türkiye'de faaliyet gösteren işletmelerin önemli bir kısmını oluşturan küçük ve mikro işletmeler, finansal raporlama ve muhasebe işlemlerinde Vergi Usul Kanunu (VUK) ve Muhasebe Sistemi Uygulamaları Genel Tebliği (MSUGT) düzenlemelerini esas almaktadır. İşletmelerde VUK hükümleri dikkate alınarak yapılan değerlemeler, MSUGT düzenlemeleri çerçevesinde muhasebeleştirilip raporlanmaktadır. Günümüzde küresel ölçekte artan ticari ve finansal ilişkiler, finansal tablo kullanıcılarının güvenilir ve karşılaştırılabilir finansal bilgiye olan ihtiyacını beraberinde getirmektedir. İşletmelerde vergi kanunları esas alınarak muhasebeleştirme yapılması ve VUK hükümlerinin gerçeğe uygun sunum noktasında yetersiz kalması, küçük ve mikro işletmelerde finansal tabloların uluslararası standartlara uyumunu zorlaştırmaktadır. KGK tarafindan bu amaçla küçük ve mikro işletmeler için uluslararası standartlarla uyumlu muhasebe standartları hazırlanmış ve 12.07.2019 tarihinde taslak metin olarak yayımlanmıştır.

İşletmelerin varlıklarının büyük bir kısmını oluşturan ve faaliyetlerinin yürütülmesinde önemli yer tutan stoklara ilişkin düzenlemeler, KÜMİ FRS Bölüm 8'de ele alınmaktadır. Bölüm 8'de, standardın kapsamı, stokların ölçümü, maliyet ölçüm teknikleri ve hesaplama yöntemleri, değer düşüklüğü ve finansal tablo dışı bırakma gibi düzenlemeler yer almaktadır.

KÜMİ FRS, ekonomideki birçok işletme için, finansal raporlama ve muhasebe alanında önemli değişiklikleri beraberinde getirecektir. Bu çalışmayla amaçlanan, işletmeler için önemli bir varlı kalemi olan stokların KÜMİ FRS kapsamında nasıl muhasebeleştirileceğini ortaya koymak ve KÜMİ FRS'nin stoklarla ilgili hükümlerini diğer standart ve uygulamalarla karşılaştırmaktır. Bu doğrultuda öncelikle literatürdeki stoklarla ilgili çalışmalar incelenmiştir. Ardından KÜMİ FRS ve içeriği aktarılmış ve KÜMİ FRS stoklar bölümü incelenerek VUK/MSUGT, TMS/TFRS, BOBİ FRS ile karşılaştırması yapılmıştır. Çalışmanın son kısmında ise, stokların KÜMİ FRS kapsamında muhasebeleştirilmesi üzerinde durulmuştur.

KÜMİ FRS henüz taslak aşamasında olan yeni bir standarttır. Bu alanda literatürde yapılan çalışmalar olsa da stoklara ilişkin hükümleri değerlendiren bir çalışma bulunmamaktadır. Bu açıdan özgün bir nitelik taşıyan çalışmanın standardın uygulanması noktasında ilgili kişi ve kurumlara fayda sağlayacağı düşünülmektedir.

\section{LITERATÜR}

Literatür incelemesi yapılırken öncelikle KÜMİ FRS alanındaki çalışmalar taranmış, daha sonra TMS/TFRS ve BOBİ FRS'de, stoklar özelinde yapılmış çalışmalar incelenmiştir. $\mathrm{Bu}$ çalışmaların bazıları aşağıda sıralanmıştır.

Akbulut ve Can (2020), KÜMİ FRS taslağını inceledikleri çalışmalarında, taslağın temel özellikleri ve kapsadığı işletmeler hakkında bilgi vermişlerdir. KÜMİ FRS'nin TFRS ve BOBİ FRS'den farklılıklarını belirtip, muhasebe uygulamalarına muhtemel etkilerini ortaya koymuşlardır.

Aytaç ve Gençoğlu (2020), maddi duran varlıkların TFRS, BOBİ FRS KÜMİ FRS taslağı ve MSUGT açısından muhasebe uygulamalarını, birbirleri arasındaki benzerlik ve 
farklılıklarına göre incelemişlerdir. TFRS, BOBİ FRS ve KÜMİ FRS taslağı çerçevesinde çok sayıda benzerlik bulmuşlar, borçlanma maliyetleri ve vade farkı ayrıştırılması hususunda farklılıklar tespit etmişlerdir. Çalışmada, maddi duran varlıkların izleyen dönemlerdeki ölçümü ve amortismanlar konusunda da önemli farklılıklar olduğu belirtilmiştir.

Gençoğlu (2020), KÜMİ FRS taslağını, BOBİ FRS ve ülkedeki vergi uygulamalarıyla karşılaştırmıştır. Çalışmada, temel kavramlar, finansal tablolar, hasılatın raporlanması, stoklar ve satışların maliyetinin raporlanması, finansal varlık ve yükümlülüklerin raporlanması, maddi ve maddi olmayan duran varlıkların raporlanması, devlet teşvikleri ve yabancı para çevirim işlemleri konularında standartlar arası karşılaştırma yapılmıştır.

Kıymetli Şen ve Özbirecikli (2020), KÜMİ FRS taslağını, TMS/TFRS, BOBİ FRS ve MSUGT/VUK ile karşılaştırmışlar sağlayacağı faydaları ve olası etkilerini inceleme konusu yapmışlardır. Çalışmada KÜMİ FRS Stoklar bölümünün, ilk ölçüm, değer düşüklüğünün tespiti ve vade farkı ayrıştırılması konusundaki hükümlerinin VUK hükümleri ile, maliyet yöntemleri hükümlerinin ise BOBİ FRS ile paralellik gösterdiği tespit edilmiştir.

Gökçen vd. (2019), KÜMİ FRS taslağı bölümlerini, BOBİ FRS ve TMS TFRS setleriyle temel konular açısından karşılaştırmışlar, uygulayıcılar için rehberlik edecek bir çerçeve sunmuşlardır. Çalışmada KÜMİ FRS seti taslağındaki stoklar bölümün, diğer standartlardaki stoklar bölümleriyle aralarındaki en büyük farkın stoklar üzerindeki finansman giderlerinin raporlanması hususunda olduğuna vurgu yapılmıştır.

Kılınç ve Badem (2020), çalışmalarında TMS 2 Stoklar standardına göre işletmelerin farklı kapasite seviyelerinde hangi maliyet yöntemini kullanacaklarını örnek uygulama üzerinden ortaya koymuşlardır. Buna göre normal kapasitenin fiili kapasiteden yüksek olması durumunda normal maliyet yöntemi, aksi durumda ise tam maliyet yönteminin uygulanması gerektiği sonucuna varmışlardır.

Taştan vd. (2020), emtia alımlarında vade farklarının nasıl muhasebeleştirileceğini TMS 2 Stoklar Standardı ve VUK hükümlerine göre aralarındaki farkları incelemişler ve dönem karı üzerindeki etkilerini ortaya koymuşlardır.

Kurtlu ve Gobi (2020), konaklama işletmelerinde üretim süreci henüz bitmemiş ya da bitse bile satılıp gelir kaydedilmemiş hizmet üretim maliyetlerinin TMS 2 Stoklar standardına göre nasıl muhasebeleştirileceği konusunda önerilerde bulunmuşlardır.

Arısoy ve Tuğay (2019), stoklarla ilgili VUK, TMS ve BOBİ FRS kapsamındaki hükümleri karşılaştırarak stok maliyet yöntemleri üzerine bir uygulama çalışması yapmışlardır.

Yalçın (2019), stokların muhasebeleştirme, değerleme ve stok maliyetlerinin belirlenmesi açısından TFRS, BOBİ FRS ve MSUGT düzenlemeleri arasındaki farkları ortaya koymuştur.

Selvi ve Ercan (2018), BOBİ FRS Bölüm 6 da yer alan stoklara ilişkin muhasebe ilkelerini, TMS 2 stoklar standardı ve VUK hükümleri ile karşılaştırmalı analiz edip yorumlarmışlardır. 
Marşap ve Barışçı (2014), bir sanayi işletmesi üzerinde yaptıkları çalışmada TMS 2 Stoklar standardının önerdiği normal maliyet yöntemiyle VUK'un uygun bulduğu tam maliyet yöntemi arasındaki farkları ürün bazında maliyet farklarını tespit ederek ortaya koymuşlardır.

Tuğay (2013), çalışmasında TMS 2 ve mevcut vergi uygulamalarına göre stoklarda değer düşüklüğü ve değer düşüklüğünün iptalinin karşılaştırmasını yapmıştır. Benzerlik ve farklılıkları ortaya konduğu çalışma örnek muhasebe uygulamalarıyla desteklenmiştir.

Akın ve Kurşunel (2010), TMS'ye göre stoklarda özellik arz eden durumları incelemişler ve TMS 2'yi SPK, TTK ve VUK düzenlemeleriyle karşılaştırmışlardır. Çalışmalarında özellikle stokların değerlemesinde maliyet unsuru, net gerçekleşebilir değer ve stokların gider kaydedilmesi konularında muhasebe örneklerine yer vermişlerdir.

Boyar ve Güngörmüş (2006), safha maliyet yöntemini uygulayan bir işletme için TMS 2 Stoklar standardında önerilen normal maliyet ile tam maliyet yöntemini karşılaştırmışlardır. Olumlu ve olumsuz sapmaları tespit etmişler, iki yöntem arasındaki birim maliyet düzeyinde farklılıkları hesaplamışlardır.

\section{KÜMİ FRS VE BÖLÜM 8 STOKLAR}

\subsection{KÜMİ FRS}

Türkiye'de uluslararası standartlara uyumlu, finansal raporlama ve muhasebe standartlarının oluşturulması sürecinde, Kamu Gözetimi Muhasebe ve Denetim Standartları Kurumu (KGK) tarafından 2017 yılında yayımlanan Büyük ve Orta Boy İşletmeler için Finansal Raporlama Standardı (BOBİ FRS) ile, Kamu Yararını İlgilendiren Kuruluşlar (KAYİK) ve büyük ve orta boy işletmeler için gerekli düzenlemeler tamamlanmıştır. Bağımsız denetime tabi olmayan küçük ve mikro işletmeler ise yürürlükteki VUK/MSUGT çerçevesinde işlemlerine devam etmektedirler. 2019 y1lına gelindiğinde ise KGK, küçük ve mikro işletmeler için gerçeğe uygun ve karşılaştırılabilir mali tabloların oluşturulabilmesi amaciyla KÜMİ FRS'nin oluşturulmasına karar vermiş ve 22 bölüm 105 sayfadan oluşan taslak standart metnini kamuoyunun görüşüne sunmuştur. $\mathrm{Bu}$ standartların uygulanmaya başlanmasıyla birlikte vergi temelli muhasebe yaklaşımından bilgi temelli muhasebe yaklaşımına geçilerek, gerçeğe uygun sunum ve karşılaştırılabilirlik noktasında tabana yayılım sağlanmış olacaktır. Türkiye'de KÜMİ FRS taslağının yayınlanmasıyla birlikte oluşacak finansal raporlama çerçevesi Şekil 1'de gösterilmiştir; 


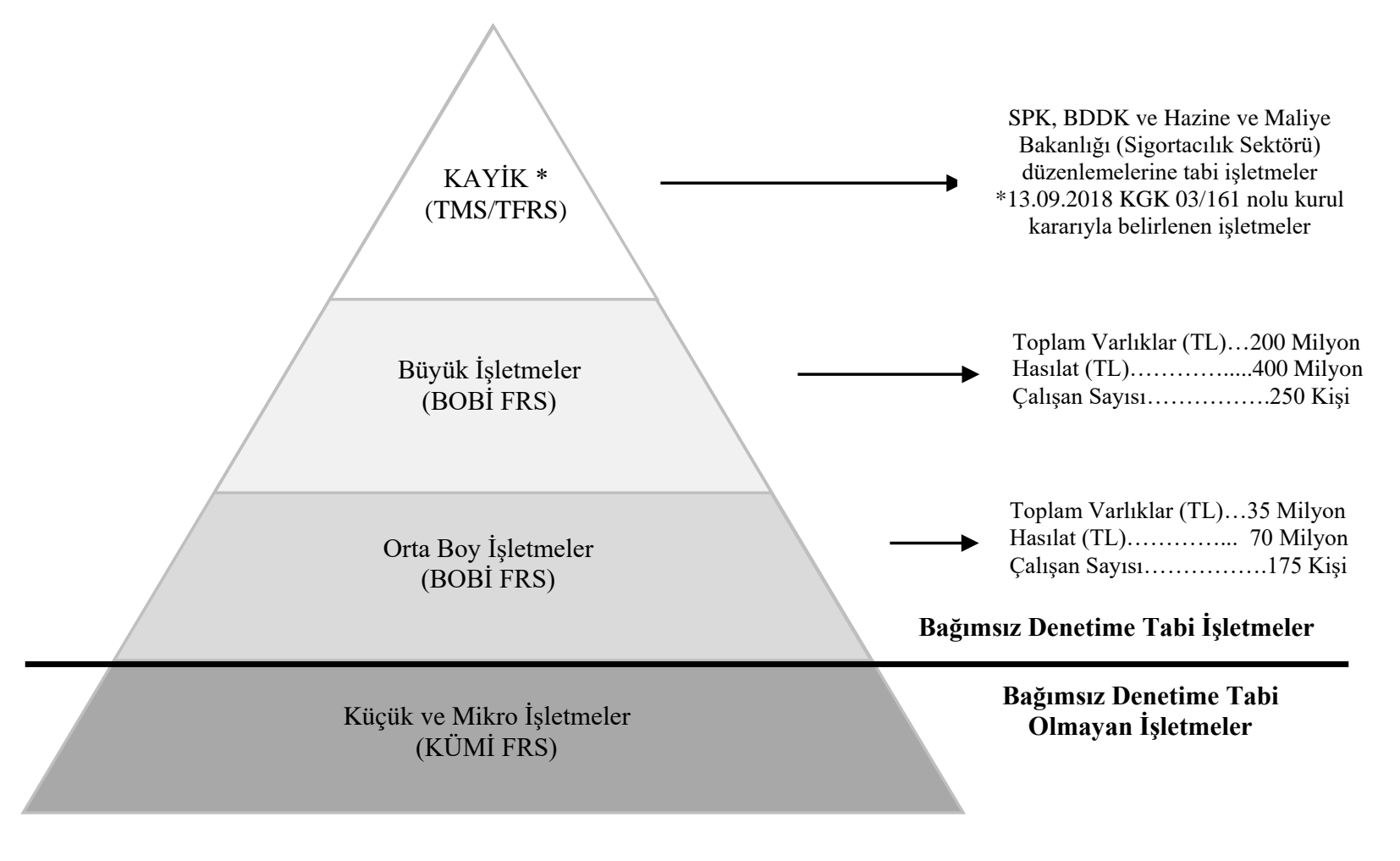

\section{Şekil 1. Türkiye'deki Finansal Raporlama Çerçevesi}

Kaynak: www.kgk.gov.tr

Sade bir anlatım diline sahip olan KÜMİ FRS, uygulayıcılar için daha az maliyetli olacak şekilde tasarlanmıştır. Örneğin, bu doğrultuda TMS/TFRS ve BOBİ FRS'den farklı olarak işletmelerden sadece "Finansal Durum Tablosu" ve "Kar veya Zarar Tablosu" hazırlanması beklenmektedir. Ayrıca standarda ilk geçişte, daha önce TFRS veya BOBİ FRS'yi uygulayan işletmeler hariç olmak üzere, geçmiş dönemlere ait finansal tabloların karşılaştırmalı olarak sunulması istenmemektedir ( KÜMİ FRS, 22/3).

Maliyet esaslı bir yaklaşım benimseyen KÜMİ FRS, işletmelerin karşılaşabileceği tüm muhasebe işlemleri ile ilgili bilgileri ve MSUGT'u tamamlayıcı uygulamaları içermektedir. Konsolidasyon ve ertelenmiş vergi gibi detaylardan arındırılarak hazırlanmıştır. Türkiye ekonomisinde yer alan çok sayıda küçük ve mikro işletme için gerçeğe uygun ve karşılaştırılabilir finansal bilginin hazırlanmasında önemli bir standart taslağıdır.

\subsection{Bölüm 8 Stoklar}

Çalışmanın bu bölümünde KÜMİ FRS'de sekizinci bölümde yer alan stoklara ilişkin hükümler, Türkiye'deki mevcut diğer uygulama ve standartlar dikkate alınarak incelenmiştir.

\subsubsection{Kapsam}

KÜMİ FRS'ye göre işletmelerin satmak amacıyla envanterinde bulundurduğu varlıklar (ticari mal, mamül), henüz üretimi tamamlanmamış yarı mamuller ve mal ve hizmet üretiminde kullanılacak ilk madde ve malzemeler, stok kapsamında değerlendirilir. Stokların 
kapsamına inşaat sözleşmelerine göre tamamlanmamış işler ve tarımsal faaliyetlerle ilgili hasat zamanındaki tarımsal ürünler ve canlı varlıklar girmemektedir.

\subsubsection{Satın Alma Maliyetleri}

Satın alma maliyeti, stok kapsamındaki varlıkların alış bedeli ile geri alınamayan ithalat vergileri ve diğer tüm vergiler, lojistik giderleri ve stokların iktisap edilmesiyle alakalı tüm maliyetleri içerir. Ayrıca varsa bu maliyetlerden iskonto ve indirimler düşülür. Stokların satın alma maliyetlerinde vade farkları indirgenmeden stok maliyetine dahil edilir. Stoklar satın alıma esas toplam tutar üzerinden ölçülür. Ayrıca ilgili stokların temin edilmesi sırasında ortaya çıkan borçlanma maliyetleri kar ya da zarar olarak gösterilir (KÜMİ FRS, 2019: 34).

Satın alma maliyetleri hususunda KÜMİ FRS hükümleri VUK/MSUGT, TMS/TFRS ve BOBİ FRS hükümleriyle paralellik göstermektedir. Ancak, KÜMİ FRS ve MSUGT'da vadeli alımlarda vade farkı ayrımı yapılmazken, TMS/TFRS'de satın alım sırasındaki vade farkları mutlaka ayrıştırılır. BOBİ FRS'de ise vade farkı ayrıştırması vadenin bir yıldan uzun olması durumunda gerçekleştirilir. Borçlanma maliyetleri konusunda ise KÜMİ FRS madde 15.3'e göre maliyetler oluştukları dönemde doğrudan kar ya da zarar olarak gösterilir. Borçlanma maliyetlerinin VUK kapsamında nasıl ele alınacağı ve raporlanacağı, 283 nolu VUK genel tebliğinde belirtilmiştir. Buna göre işletmeler, yurtiçi borçlanmalarından kaynaklanan faiz ve komisyon giderlerini, isterlerse doğrudan gider olarak gösterilebilecek, isterlerse stokta bulunan emtiaya isabet eden kısmını maliyete dahil edebileceklerdir (VUK Tebliği, 1995). TMS/TFRS'de ise borçlanma maliyetleri, özellikli varlık statüsünde olan, üretimi veya satışı uzun vadede gerçekleşen stoklarda istenirse stok maliyetine ilave edilebilir. BOBİ FRS'de borçlanma maliyetleri, üretimi bir yıldan fazla süren stok kalemleri için stok maliyetlerine eklenir.

\subsubsection{Dönüştürme Maliyetleri}

KÜMİ FRS 8. Bölüm 10. paragrafta dönüştürme maliyetlerinin kapsamı açıklanmış, 11 ve 12. paragraflarda ise dönüştürme maliyetlerinin tespitinde kullanılabilecek yöntemler sıralanmıştır. Buna göre, dönüştürme maliyetleri üretim süreciyle direkt ilişkisi kurulabilen maliyetlerden oluşur. Faaliyet giderleri ise bu maliyetlerin içine dahil edilmez. Dönüştürme maliyetlerinin tespitinde KÜMI'ler isteğe bağlı olarak tam maliyet ya da normal maliyet yöntemini tercih edebilirler. KÜMİ FRS madde 8.11 'de de belirtildiği gibi “Tam maliyet yönteminde, sabit ve değişken genel üretim giderlerinin tamamı dönüştürme maliyetine dâhil edilir. Ancak faaliyetleri geçici veya kalıcı olarak durdurulan ya da henüz faaliyete geçmemiş bölümlere ilişkin sabit genel üretim giderleri dönüşürme maliyetine dâhil edilmez, gider olarak "Satışların Maliyeti" kaleminde gösterilir". Normal maliyet yönteminde ise, değişken genel üretim giderlerinin tamamı, sabit genel üretim giderlerinin ise kapasite kullanımına isabet eden kısmı dönüştürme maliyetine dahil edilir. Dağıtılmayan genel üretim gideri ise, gerçekleştiği dönemde "Satışların Maliyeti" kaleminde gösterilir. KÜMİ FRS'ye göre "normal maliyet yönteminin kullanılması durumunda, değişken genel üretim giderleri de üretim tesislerinin fiili kullanımına bağlı olarak her bir üretim birimine dağıtılır”.

BOBİ FRS dönüştürme maliyetleri hususunda KÜMİ FRS ile birebir uyumludur. TMS/TFRS' de dönüştürme maliyetlerinde yöntem olarak sadece normal maliyet yöntemi esas alınmaktadır. VUK/MSUGT çerçevesinde üretim maliyetlerinin tespitinde tam maliyet 
yöntemi kullanılır. Bu yöntemde üretimle ilgili bütün maliyetler mamulün maliyetine yüklenirken, genel üretim giderlerinin sabit ve değişken bölümlerini birbirinden ayırmaya gerek yoktur. Bu durum da yöntemin kullanımını oldukça basitleştirmektedir. VUK tam maliyet yöntemini önererek stokların dönüştürme maliyetinin hesaplanmasında mükelleflere kolaylık sağlamaktadır.

\subsubsection{Hizmet İşletmelerinde Stok Maliyeti}

KÜMİ FRS'ye göre hizmet üreten işletmelerde stok bulunması halinde, stok maliyetleri hizmetin sunulmasında doğrudan görev alan personel giderleriyle ve hizmetle doğrudan ilişkilendirilebilen giderlerden oluşur. Hizmet üretimiyle doğrudan ilişkilendirilemeyen satı̧s ve yönetim giderleri gibi giderler oluştukları dönemde kar zarar hesaplarına aktarılır (KÜMİ FRS,8/14).

BOBİ FRS'nin hizmet işletmelerinde stok maliyetine ilişkin hükümleri KÜMİ FRS ile uyumludur. TMS/TFRS 2020 setinde ise TMS 2 Stoklar standardı kapsamında hizmet işletmelerinde stok maliyetine ilişkin hükümler silinmiş ve bu husus TFRS 15 Müşteri Sözleşmelerinden Hasılat standardıyla ilişkilendirilmiştir. Buna göre, maliyetlerin doğrudan bir sözleşmeyle ilişkili olması ve geri kazanılmasının beklenmesi durumunda işletme, söz konusu maliyetleri varlık olarak mali tablolara alacaktır. Dikkat edilmesi gereken husus hizmet maliyetlerinin geri kazanılabilir olmasıdır. Verilen hizmetle alakalı geri kazanılabilecek giderler aktifleştirilirken, diğerleri zarar olarak muhasebeleştirilir. KGK'nın finansal raporlama standartlarına uygun olarak yayınladığı taslak hesap planında ise, hizmet işletmelerinde üretim maliyetleri gerçekleşmiş ancak henüz üretimi tamamlanmamış hizmetlerin

"154 Tamamlanmamış Hizmet Maliyeti" hesabında, üretimi tamamlanmış ancak henüz satılmadığı için gelir elde edilmemiş stok niteliğindeki hizmetlerin maliyetleri ise "155 Tamamlanmış Hizmet Maliyetleri" hesabında izleneceği belirtilmiştir. (KGK Taslak Hesap Planı, 2018: 19-20). VUK/MSUGT 'da ise hizmet işletmelerinde ortaya çıkan maliyetlere ilişskin aktifleştirme gibi bir hüküm bulunmamakta, oluşacak maliyetler doğrudan gider olarak muhasebeleştirilmektedir.

\subsubsection{Maliyet Ölçüm Teknikleri}

KÜMİ FRS'de mamul maliyetlerinin tespitinde dönemde ortaya çıkan fiili maliyetler esas alınır. Ancak standart maliyet yöntemi veya perakende yöntemi sonuçlarının fiili maliyet sonuçlarına yakın olduğu durumlarda bu iki yöntem de ölçüm tekniği olarak uygulanabilir. Standart maliyet yönteminde fiili sonuçlar beklenmeden maliyeti oluşturan giderlerin standart tutarları esas alınır. Perakende yönteminde ise maliyetler, stokların satış fiyatından tahmini kar tutarının indirilmesiyle hesaplanır (KÜMİ FRS, B8. 16).

Stok maliyetlerinin ölçümünde KÜMİ FRS, BOBİ FRS, TMS/TFRS hükümleri birbirleriyle uyumludur. TMS 2 Stoklar standardında perakende yönteminin kimler tarafindan uygulanabileceği ve nasıl uygulanması gerektiğine ilişkin ayrıntılı bilgiler bulunmaktadır. VUK/MSUGT'da ise işletmeler maliyet ölçümünde istedikleri yöntemi kullanabilirler. Ancak maliyetlerin VUK md.275 'de belirtilen unsurları içermesi gerekir. 


\subsubsection{Stok Değerleme Yöntemleri}

KÜMİ FRS'ye göre stokların maliyeti, Gerçek Parti Maliyet Yöntemi, İlk Giren İlk Çıkar (FIFO) Yöntemi, Ağırlıklı Ortalama Maliyet Yöntemlerinden uygun olan birisi seçilerek hesaplanır. Son Giren İlk Çıkar (LIFO) yöntemi ise kullanılamaz. İşletmeler, cinsi ve kullanım yerleri farklı olan stok kalemlerini değerlerken farklı yöntemleri kullanabilirken tutarlılık ilkesi gereği aynı tür stoklar için aynı maliyet hesaplama yöntemini kullanmak zorundadırlar (KÜMİ FRS, B8. 17). Bu hükümler, VUK/MSUGT, BOBİ FRS ve TMS/TFRS ile uyumludur.

\subsubsection{Stoklarda Değer Düşüklüğü}

KÜMİ FRS'ye göre dönem sonu envanter işlemlerinde stokların değerlemesi yapılırken, stokların tahmini satı̧ fiyatının maliyet bedelinden yüzde 10 veya daha fazla düşük olması durumunda oluşacak kayıp değer düşüklüğü zararı olarak finansal tablolara yansitılır. Bu zarar, kar veya zarar tablosunda satışların maliyeti hesap grubunda muhasebeleştirilir. İzleyen dönemde daha önce değer düşüklüğüne uğramış olan stokların satış fiyatlarında oluşacak artış değer düşüklüğü zararının tamamının veya bir kısmının iptal edilmesini gerektirir (KÜMİ FRS, B8. 19).

VUK 274. maddesine göre stoklar maliyet bedeli ile değerlenir. Ancak stokların piyasa fiyatı maliyet bedeline göre $\% 10$ veya daha fazla bir oranda düşmesi durumunda stoklar maliyet bedeli yerine emsal bedel ile değerlenebilir. Değer kaybının \%10'dan daha düşük olması durumunda maliyet bedeli esas alınır. Dolayısıyla KÜMİ FRS ile VUK hükümleri birbirleriyle uyumludur. BOBİ FRS ve TMS/TFRS 'de ise emsal bedel ya da tahmini satış fiyatı kavramı yerine, net gerçekleşebilir değer kavramı üzerinde durulmuştur. Buna göre net gerçekleşebilir değer tahmini satış fiyatından tahmini tamamlama maliyeti ve satış giderlerinin düşülmesiyle bulunur ve bu değerin maliyet bedelinin altına düşmesi durumunda değer düşüklüğü zararı finansal tablolara yansıtılır.

\subsubsection{Stokların Elden Çıkarılması}

İşletme stokları satışa konu olduğunda, defter değerleri, satış hasılatının gerçekleştiği dönemde finansal tablolarda satışların maliyeti olarak gösterilir. İlgili stoklar işletmede kullanıldıklarında ise, maliyet ilgili varlı̆ı̆n maliyetine dahil edilir ve ekonomik ömrü boyunca itfa edilir (KÜMİ FRS, B8. 21). Stokların elden çıarılmasına ilişkin bu hususlar, tüm standart ve uygulamalarda birbiriyle uyumludur.

\subsection{Stoklara İlişskin Hükümlerin VUK/MSUGT, TMS/TFRS, BOBİ FRS ve KÜMİ FRS Çerçevesinde Karşılaş̧ırııması}

Çalışmanın bu kısmında toplu bir sunum sağlaması açısından stoklara ilişkin hükümler VUK/MSUGT, TMS/TFRS, BOBİ FRS ve KÜMİ FRS çerçevesinde incelenmiş, aralarındaki benzerlik ve farkl11ıklar Tablo 1'de ortaya konmuştur. 
Tablo 1. Stokların Mevcut Uygulama ve Standartlardaki Durumu

\begin{tabular}{|c|c|c|c|c|}
\hline İçerik & TMS/TFRS & BOBİ FRS & KÜMİ FRS & VUK/MSGUT \\
\hline $\begin{array}{l}\text { Satın Alma } \\
\text { Maliyetleri }\end{array}$ & $\begin{array}{l}\text { VUK/MSUGT ile } \\
\text { uyumludur }\end{array}$ & $\begin{array}{l}\text { VUK/MSUGT ile } \\
\text { uyumludur }\end{array}$ & $\begin{array}{l}\text { VUK/MSUGT ile } \\
\text { uyumludur }\end{array}$ & $\begin{array}{l}\text { Satın alma } \\
\text { maliyeti, stok } \\
\text { kapsamındaki } \\
\text { varlıkların alış } \\
\text { bedeli ile geri } \\
\text { alınamayan ithalat } \\
\text { vergileri ve diğer } \\
\text { tüm vergiler, } \\
\text { lojistik giderleri ve } \\
\text { stokların iktisap } \\
\text { edilmesiyle alakalı } \\
\text { tüm maliyetleri } \\
\text { içerir. }\end{array}$ \\
\hline Vade Fark1 & $\begin{array}{l}\text { Bütün vade farkları } \\
\text { ayrıştırılır. }\end{array}$ & $\begin{array}{l}1 \text { yıldan uzun } \\
\text { vadeli alımlarda } \\
\text { vade farkı } \\
\text { ayrıştırılır. }\end{array}$ & $\begin{array}{l}\text { VUK/MSUGT ile } \\
\text { uyumludur }\end{array}$ & $\begin{array}{l}\text { Stokların satın } \\
\text { alma } \\
\text { maliyetlerinde } \\
\text { vade farkları } \\
\text { ayrıştırılmaz. }\end{array}$ \\
\hline $\begin{array}{l}\text { Borçlanma } \\
\text { Maliyetleri }\end{array}$ & $\begin{array}{l}\text { Özellikli varlık } \\
\text { statüsünde olan, } \\
\text { üretimi veya satışı } \\
\text { uzun vadede } \\
\text { gerçekleşen } \\
\text { stoklarda istenirse } \\
\text { stok maliyetine } \\
\text { ilave edilebilir }\end{array}$ & $\begin{array}{l}\text { Üretimi bir yildan } \\
\text { fazla süren stok } \\
\text { kalemleri için } \\
\text { stoka eklenir }\end{array}$ & $\begin{array}{l}\text { Doğrudan kar ya } \\
\text { da zarar olarak } \\
\text { gösterilir. }\end{array}$ & $\begin{array}{l}\text { Borçlanmalardan } \\
\text { kaynaklanan faiz } \\
\text { ve komisyon } \\
\text { giderleri, istenirse } \\
\text { doğrudan gider } \\
\text { olarak raporlanır, } \\
\text { istenirse stokta } \\
\text { bulunan emtia } \\
\text { maliyetine dahil } \\
\text { edilir. }\end{array}$ \\
\hline $\begin{array}{l}\text { Dönüştürme } \\
\text { Maliyetleri }\end{array}$ & $\begin{array}{l}\text { Normal maliyet } \\
\text { yöntemi }\end{array}$ & $\begin{array}{l}\text { Tam maliyet veya } \\
\text { normal maliyet } \\
\text { yöntemi }\end{array}$ & $\begin{array}{l}\text { BOBİ FRS ile } \\
\text { uyumludur. }\end{array}$ & $\begin{array}{l}\text { Tam maliyet } \\
\text { yöntemi }\end{array}$ \\
\hline $\begin{array}{l}\text { Hizmet } \\
\text { İşletmelerinde } \\
\text { Stok Maliyeti }\end{array}$ & $\begin{array}{l}\text { Bir sözleşmeyle } \\
\text { ilişkili ve geri } \\
\text { kazanılabilir } \\
\text { giderler } \\
\text { aktifleştirilir. Diğer } \\
\text { giderler zarar } \\
\text { olarak } \\
\text { muhasebeleştirilir. }\end{array}$ & $\begin{array}{l}\text { Hizmet satışıyla } \\
\text { doğrudan } \\
\text { ilişkilendirilebilen } \\
\text { maliyet ve giderler } \\
\text { stoklar grubunda } \\
\text { aktifleştirilir. Diğer } \\
\text { giderler zarar } \\
\text { olarak } \\
\text { muhasebeleştirilir }\end{array}$ & $\begin{array}{l}\text { BOBİ FRS ile } \\
\text { uyumludur. }\end{array}$ & $\begin{array}{l}\text { Aktifleştirmeye } \\
\text { yönelik bir hüküm } \\
\text { bulunmamaktadır. } \\
\text { Oluşacak } \\
\text { maliyetler } \\
\text { doğrudan gider } \\
\text { olarak } \\
\text { muhasebeleştirilir. }\end{array}$ \\
\hline $\begin{array}{l}\text { Maliyet Ölçüm } \\
\text { Teknikleri }\end{array}$ & $\begin{array}{l}\text { Dönemde ortaya } \\
\text { çıkan fiili } \\
\text { maliyetler esas } \\
\text { alınır. Ancak } \\
\text { standart maliyet } \\
\text { yöntemi veya } \\
\text { perakende yöntemi } \\
\text { sonuçlarının fiili } \\
\text { maliyet } \\
\text { sonuçlarına yakın } \\
\text { olduğu durumlarda } \\
\text { bu iki yöntem de } \\
\text { ölçüm tekniği }\end{array}$ & $\begin{array}{l}\text { TMS/TFRS ile } \\
\text { uyumludur. }\end{array}$ & $\begin{array}{l}\text { TMS/TFRS ile } \\
\text { uyumludur. }\end{array}$ & $\begin{array}{l}\text { İşletmeler fiili } \\
\text { maliyet yöntemi, } \\
\text { standart maliyet } \\
\text { yöntemi ve tahmini } \\
\text { maliyet } \\
\text { yöntemlerinden } \\
\text { istedikleri yöntemi } \\
\text { kullanabilirler. }\end{array}$ \\
\hline
\end{tabular}




\begin{tabular}{|c|c|c|c|c|}
\hline & $\begin{array}{l}\text { olarak } \\
\text { uygulanabilir. }\end{array}$ & & & \\
\hline $\begin{array}{l}\text { Stok Değerleme } \\
\text { Yöntemleri }\end{array}$ & $\begin{array}{l}\text { VUK/MSUGT ile } \\
\text { uyumludur }\end{array}$ & $\begin{array}{l}\text { VUK/MSUGT ile } \\
\text { uyumludur }\end{array}$ & $\begin{array}{l}\text { VUK/MSUGT ile } \\
\text { uyumludur }\end{array}$ & $\begin{array}{l}\text { Stokların maliyeti, } \\
\text { Gerçek Parti } \\
\text { Maliyet Yöntemi, } \\
\text { İlk Giren İlk Çıkar } \\
\text { (FIFO) Yöntemi, } \\
\text { Ağırlıklı Ortalama } \\
\text { Maliyet } \\
\text { Yöntemlerinden } \\
\text { uygun olan birisi } \\
\text { seçilerek } \\
\text { hesaplanır }\end{array}$ \\
\hline $\begin{array}{l}\text { Stoklarda Değer } \\
\text { Düşüklüğü }\end{array}$ & $\begin{array}{l}\text { Net gerçekleşebilir } \\
\text { değerin maliyet } \\
\text { bedelinin altına } \\
\text { düşmesi } \\
\text { durumunda değer } \\
\text { düşüklüğü zararı } \\
\text { finansal tablolara } \\
\text { yansıtılır. }\end{array}$ & $\begin{array}{l}\text { TMS/TFRS ile } \\
\text { uyumludur. }\end{array}$ & $\begin{array}{l}\text { VUK/MSUGT ile } \\
\text { uyumludur }\end{array}$ & $\begin{array}{l}\text { Stokların değerinde } \\
\text { \%10 veya daha } \\
\text { fazla düşüş olması } \\
\text { durumunda } \\
\text { oluşacak kayıp, } \\
\text { değer düşüklüğü } \\
\text { zararı olarak } \\
\text { finansal tablolara } \\
\text { yansitılır. }\end{array}$ \\
\hline $\begin{array}{l}\text { Stokların Elden } \\
\text { Çıkarılması }\end{array}$ & $\begin{array}{l}\text { VUK/MSUGT ile } \\
\text { uyumludur }\end{array}$ & $\begin{array}{l}\text { VUK/MSUGT ile } \\
\text { uyumludur }\end{array}$ & $\begin{array}{l}\text { VUK/MSUGT ile } \\
\text { uyumludur }\end{array}$ & $\begin{array}{l}\text { Defter değerleri, } \\
\text { satış hasılatının } \\
\text { gerçekleştiği } \\
\text { dönemde finansal } \\
\text { tablolarda satışların } \\
\text { maliyeti olarak } \\
\text { gösterilir. İlgili } \\
\text { stoklar işletmede } \\
\text { kullanıldıklarında } \\
\text { ise ekonomik ömrü } \\
\text { boyunca itfa edilir }\end{array}$ \\
\hline
\end{tabular}

Kaynak: VUK/MSUGT, TMS/TFRS, BOBİ FRS, KÜMİ FRS.

\section{STOKLARIN KÜMİ FRS KAPSAMINDA MUHASEBELEŞTİIILMESİ}

Çalışmanın bu bölümünde stokların KÜMİ FRS kapsamında muhasebeleştirilmesine yönelik örnekler verilmiştir. $\mathrm{Bu}$ örneklerde KGK tarafından 13.12.2018 tarihinde kamuoyunun görüşüne sunulan finansal raporlama standartlarına uygun hesap planı taslağı kullanılmıştır. KGK, mevcut tekdüzen hesap planını, uluslararası finansal raporlama standartlarına uyumlu hale getirmek için bu taslağı hazırlamıştır. Hesap planının kullanılmaya başlanmasıyla, bilanço usulüne göre defter tutan işletmelerin finansal tablolarının gerçeğe ve ihtiyaca uygun, anlaşılabilir ve karşılaştırılabilir olma nitelikleri artacaktır.

\section{1. İlk Alım ve Satın Alma Maliyetleri}

X Ticaret İşletmesi 01/06/2020 tarihinde yüzde 18 KDV hariç 50.000 TL'ye 3 ay vadeli senet düzenleyerek ticari mal satın almıştır. Malı depoya getirilmesi için yüzde 18 KDV hariç 1.000 TL Nakliye bedeli ve yüzde 18 KDV hariç 500 TL sigorta bedeli bankadan EFT ile ödenmiştir. 
İşletme KÜMİ FRS kapsamında stok alımlarında vade farkı ayrıştırması yapmayacak ve alış giderlerini ilgili malın maliyetine ilave edecektir.

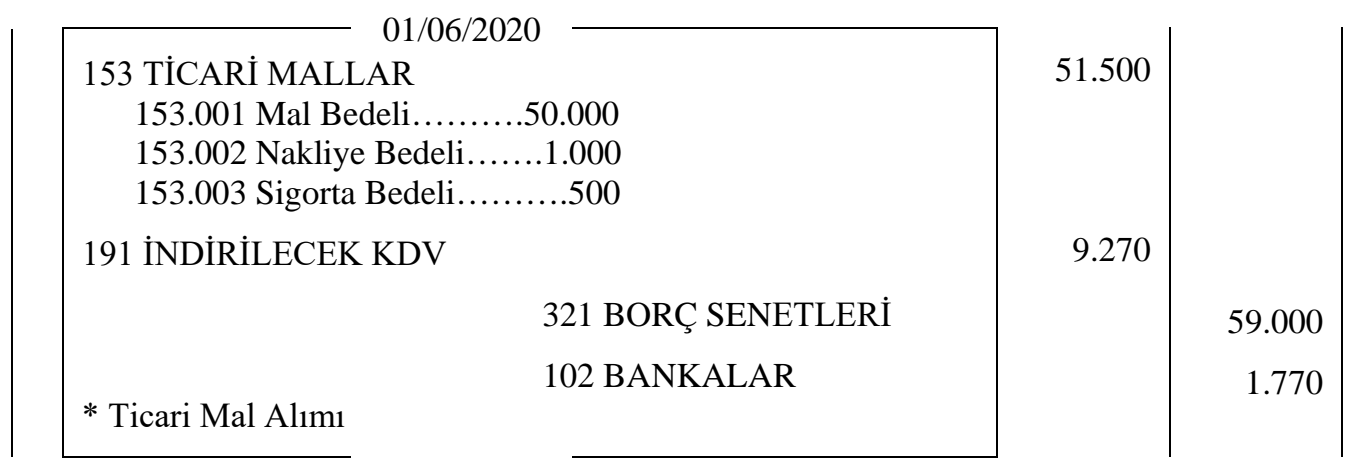

\subsection{Stokların Dönüştürme Maliyetleri}

Y Üretim İşletmesinin A mamulüne ilişkin yıllık üretim kapasitesi 5.000 adettir. İşletme 2019 yılında 3.000 adet mamul üretmiştir. Birim satış fiyatı 100 TL olup ilgili dönemde 2.500 adet mamul satışı yapılmıştır. Üretime ilişkin gerçekleşen giderler aşağıda gösterilmiştir.
D.İ.M.M. Gideri
: $120.000 \mathrm{TL}$
D.İ.G.
: $50.000 \mathrm{TL}$
Sabit G.Ü.G.
: $60.000 \mathrm{TL}$
Değişken G.Ü.G.
: $30.000 \mathrm{TL}$
Paz. Sat. Dağ. Giderleri
$: 10.000 \mathrm{TL}$
Genel Yönetim Giderleri
$: 15.000 \mathrm{TL}$

KÜMİ FRS kapsamında, stokların dönüştürülmesi noktasında işletmenin kar veya zarar tablosunda gösterilecek olan satışların maliyeti (620 Satılan Mamuller Maliyeti) ve brüt satış karı/zararı tutarları, tam maliyet ve normal maliyet yöntemlerine göre ayrı ayrı hesaplanmıştır. İşletme bu yöntemlerden istediğini seçebilir. Faaliyet giderleri mamul maliyetine dahil edilmeyecektir.

\section{Tam Maliyet Yöntemi:}

$\begin{array}{ll}\text { Toplam Üretim Maliyeti } & =\text { DİMM+DİG+GÜG }(\text { Sbt+Değ. })=240.000 \mathrm{TL} \\ \text { Birim Üretim Maliyeti } & =240.000 \mathrm{TL} / 3.000 \mathrm{ad}=80 \mathrm{TL} / \mathrm{ad} \\ \text { Satılan Mamul Maliyeti } & =2.500 \mathrm{ad} \text { x } 80 \mathrm{TL} / \mathrm{ad}=200.000 \mathrm{TL} \\ \text { Dönem Sonu Stok Maliyeti } & =240.000 \mathrm{TL}-200.000 \mathrm{TL}=40.000 \mathrm{TL} \\ \text { Brüt Satış Karı/Zararı } & =(2.500 \mathrm{ad} \text { x } 100 \mathrm{TL} / \mathrm{ad})-200.000 \mathrm{TL}=50.000 \mathrm{TL}\end{array}$

\section{Normal Maliyet Yöntemi:}

Kapasite Kullanım Oranı $\quad=3.000$ ad $/ 5.000$ ad $=$ yüzde 60 


$$
\begin{aligned}
\text { Toplam Üretim Maliyeti } & =\text { DİMM + DİG + Değ. GÜG + (Sbt. GÜG x KKO }) \\
& =120.000+50.000+30.000+(60.000 \times 0,6), ’, ” \\
& =216.000 \mathrm{TL}
\end{aligned}
$$

Birim Üretim Maliyeti $=216.000 \mathrm{TL} / 3.000 \mathrm{ad}=72 \mathrm{TL} / \mathrm{ad}$

Satılan Mamul Maliyeti $=2.500$ ad x $72 \mathrm{TL} / \mathrm{ad}=180.000 \mathrm{TL}$

Dönem Sonu Stok Maliyeti $=216.000$ TL -180.000 TL $=36.000$ TL

Brüt Satış Karı/Zararı $=(2.500 \mathrm{ad} \times 100 \mathrm{TL} / \mathrm{ad})-180.000 \mathrm{TL}=70.000 \mathrm{TL}$

Not: Kullanılmayan kapasiteye düşen Sabit G.Ü.G., KGK'nin yayınlamış olduğu Hesap planı Taslağına göre "62 Satışların Maliyetleri” hesap grubunda "624 Dağıtılmayan Sabit Genel Üretim Giderleri” hesabında muhasebeleştirilir (KÜMİ FRS, B8. 12).

\subsection{Tamamlanmamış Hizmet Maliyetleri}

ABC Yazılım Şirketi 01/09/2019 tarihinde Android tabanlı bir oyun yazılım işini üstlenmiş ve $\mathrm{X}$ işletmesine 15/02/2020 tarihinde teslim edeceğini belirtmiştir. $\mathrm{X}$ İşletmesi oyun için 20.000 TL ön ödeme yapmış kalan 30.000 TL'lik tutarı da teslim sırasında ödeyeceğini taahhüt etmiştir. ABC Yazılım Şirketi bu işle ilgili olarak toplam 25.000 TL maliyete katlanacağını hesaplamıştır. Dönem sonuna kadar oyun için 20.000 TL gider yapılmış ve banka aracılığıyla ödenmiştir. ABC Yazılım şirketinin tamamlanmamış hizmet maliyetlerine ilişkin yapması gereken muhasebe kayıtları aşağıda gösterilmiştir.

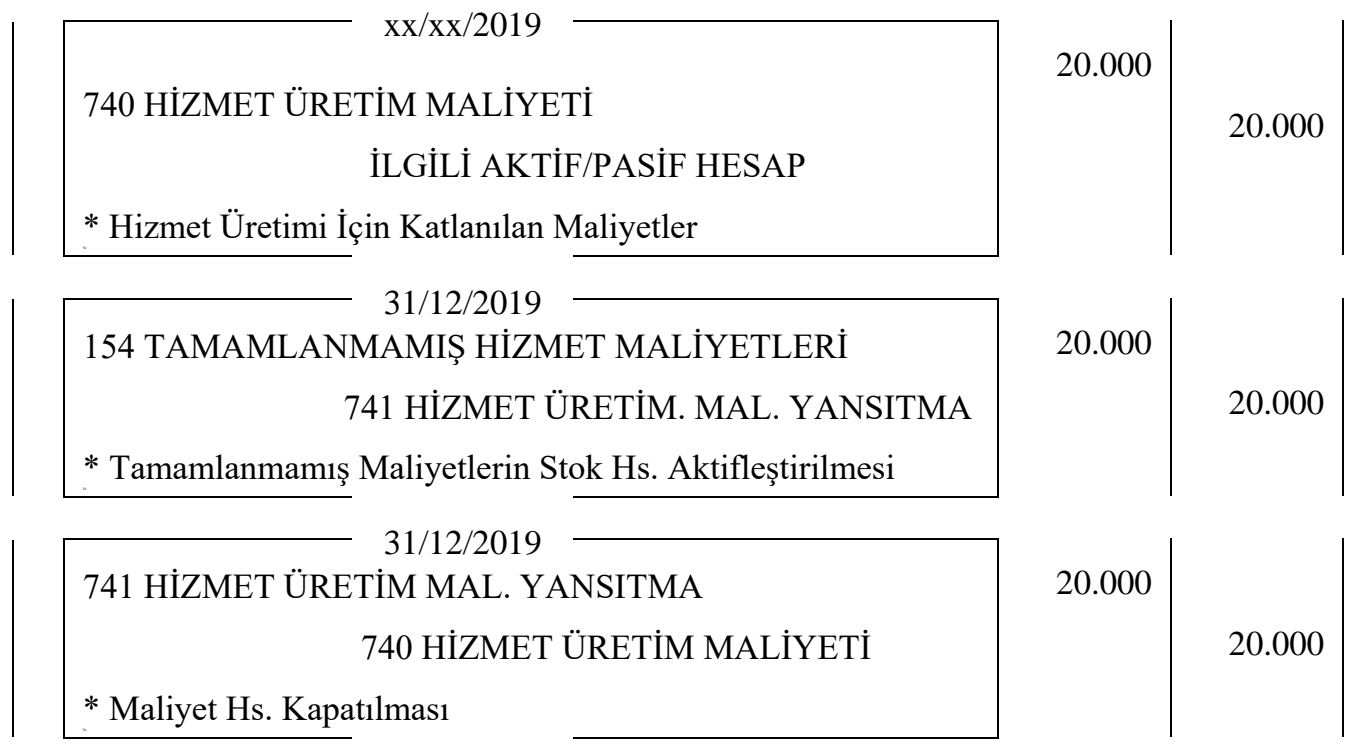

Not: İzleyen dönemde hizmet tamamlandığında 154 Tamamlanmamış Hizmet Maliyetleri hesabı kapatılarak tutar 155 Tamamlanmış Hizmet Maliyetleri hesabına aktarılır. 


\subsection{Stoklarda Değer Düşüklüğü ve Stokların Elden Çıkarılması}

Z Ticaret İşletmesi 2019 faaliyet dönemi sonunda ticari mal stoklarında bulunan ve maliyeti 100.000 TL olan ticari malın tahmini satış fiyatının,

a) $\quad 95.000 \mathrm{TL}$ olduğunu,

b) $\quad 85.000 \mathrm{TL}$ olduğunu

tespit etmiştir. İzleyen dönemde stokların yüzde 18 KDV hariç 120.000 TL'ye peşin satılmıştır. Buna göre yapılması gereken muhasebe işlemleri aşağıda gösterilmiştir.

a) KÜMİ FRS'ye göre stoklardaki değer düşüklüğü maliyet bedeline göre yüzde 10 'dan daha az değer kaybettiği için değer düşüklüğü karşılığı ayrılmayacaktır.

b) Değer düşüklüğü yüzde 15 olduğu için aşağıdaki kayıtlar yapılmalıdır.

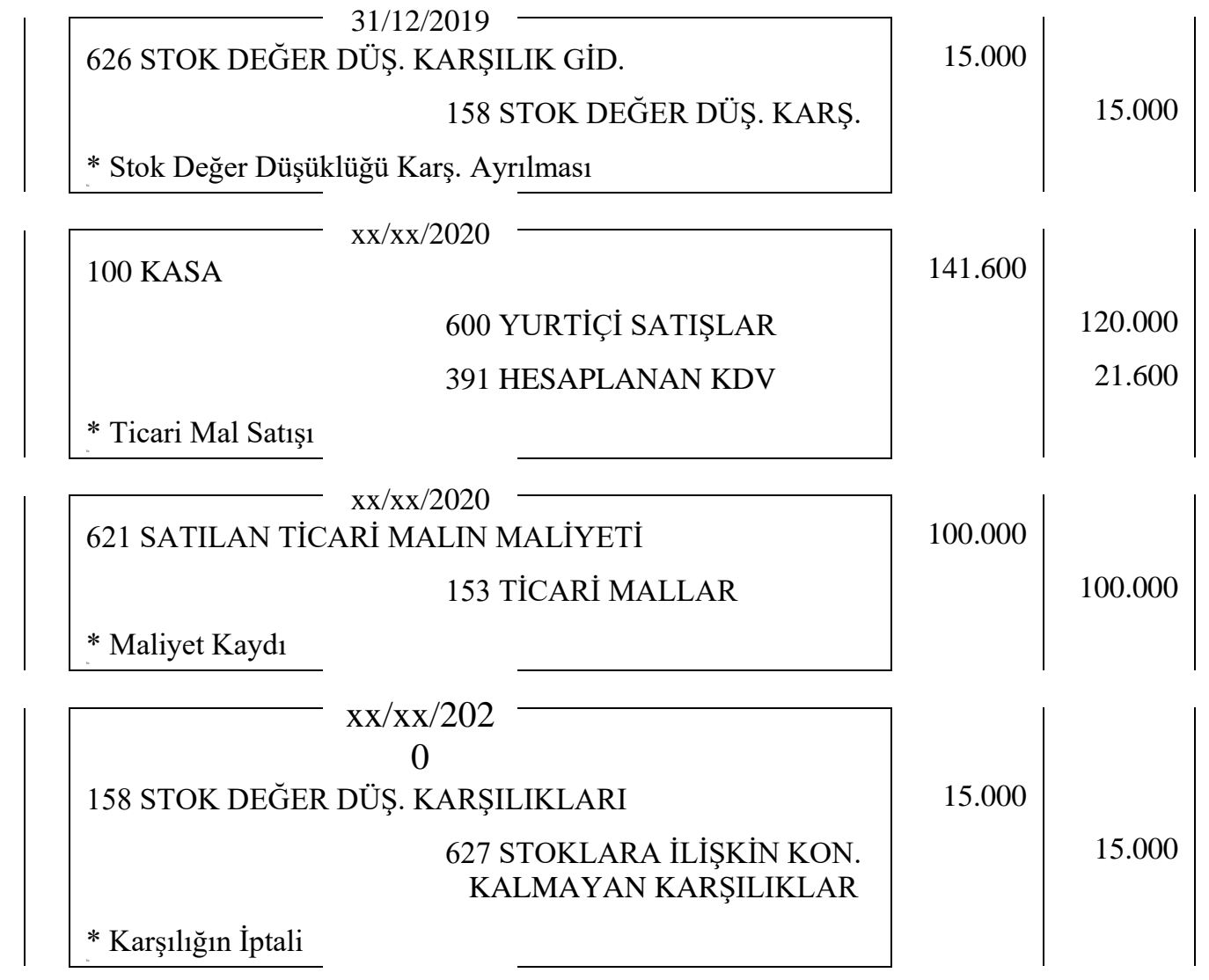

Not: Stokların elden çıkarılması yerine işletme faaliyetlerinde kullanılması durumunda, ilgili stok unsuru "15 Stoklar" hesap grubundan çıkarılarak ilgili duran varlık hesabına aktarılır ve faydalı ömrü boyunca amortismana tabi tutularak giderleştirilir (KÜMİ FRS, B8. 22). 


\section{SONUÇ VE ÖNERILLER}

VUK ve MSUGT düzenlemelerinin, işletmelerin faaliyet sonuçlarını yansıtmada gerçeğe uygunluk ve karşılaştırılabilirlik noktasında yetersiz kalması, KGK'nın uluslararası standartlarla uyumlu düzenlemelerini beraberinde getirmektedir. Bu kapsamda, KGK son olarak 12.07.2019 'da finansal raporlamada standartlaşmanın ekonominin geneline yayılması çerçevesinde küçük ve mikro işletmeler için KÜMİ FRS taslağını yayınlamıştır. Çalışmanın konusunu oluşturan stoklara ilişkin hükümler KÜMİ FRS 8. bölümde düzenlenmiş̧ir. Stoklar işletme ölçeğine bakılmaksızın faaliyetlerin yürütülmesinde önemli bir varlık unsurudur ve bunlara ilişkin ölçüm, değerleme, dönüştürme gibi özellikli durumların uluslararası standartlara uygun olarak yapılması faaliyet sonuçlarının gerçeğe yansıtması açısından son derece önemlidir.

KÜMİ FRS, stoklar açısından bakıldığında VUK ve MSUGT düzenlemelerine benzemekle beraber, dönüştürme maliyetleri, hizmet işletmelerinde stok maliyeti, maliyet ölçüm teknikleri, gibi konularda farklılıklar içermektedir. Stokların dönüştürme maliyetlerinde, VUK/MSUGT tam maliyet yöntemini esas alırken KÜMİ FRS tam maliyet ya da normal maliyet yöntemlerinin kullanılabileceğini belirtmektedir. VUK/MSUGT’a göre hizmet işletmelerinde ortaya çıkan maliyetler doğrudan gider olarak muhasebeleştirilirken, KÜMİ FRS hükümlerine göre hizmet satışıla doğrudan ilişkilendirilebilen maliyetler stoklar grubunda aktifleştirilir. Son olarak, stok maliyetlerinin ölçümünde VUK/MSUGT fiili maliyet, standart maliyet ve tahmini maliyet yöntemlerinden istenilenin kullanılabileceğini belirtirken, KÜMİ FRS fiili maliyetleri esas almaktadır.

KÜMİ FRS, TMS/TFRS ve BOBİ FRS ile karşılaştırıldığında ise stokların satın alınmasında vade farkının ayrıştırılması, borçlanma maliyetleri ve stoklarda değer düşüklüğü gibi konularda farkl11lklar olduğu görülmektedir. KÜMİ FRS'de, TMS/TFRS ve BOBİ FRS'den farklı olarak stokların satın alınmasında ödenen vade farkları stok maliyetine dahil edilir. Borçlanma maliyetleri ise hiçbir zaman stok maliyetlerine ilave edilmemektedir. Ayrıca stoklardaki değer düşüklüklerinin KÜMİ FRS 'de gider olarak gösterilebilmesi için değer kaybının minimum \%10 olması şartı aranırken, diğer standartlarda gerçekleşen değer düşüklükleri her koşulda giderleştirilecektir. Sonuç olarak, konsolidasyon ve ertelenmiş vergi gibi detaylardan da arındırılarak hazırlanan KÜMİ FRS, diğer standartlara göre daha yalın bir anlatıma sahip olduğu için işletmelere uygulama kolaylığı sağlayacaktır.

KÜMİ FRS'nin uygulanmaya başlamasıyla, Türkiye'de işletmelerin büyük bir kısmı uluslararası standartlarla uyumlu muhasebe işlemleri gerçekleştirecektir. Daha anlaşılabilir olması ve uygulama kolaylığı nedeniyle KÜMİ FRS'ye uyumun TMS/TFRS ve BOBİ FRS'ye göre daha kolay ve hızlı gerçekleşeceği düşünülmektedir. Bununla birlikte mevcut vergi temelli muhasebe sisteminden standarda geçişin nasıl sağlanacağı, kontrol ve denetimin nasıl yapılacağı konularında ciddi belirsizlikler bulunduğu düşünülmektedir. 


\section{KAYNAKLAR}

Akbulut, Emre - Can, Mustafa Emir (2020), "Küçük ve Mikro İşletmeler İçin Finansal Raporlama Standardı (KÜMİ FRS) Taslağı Hakkında”, Muhasebe Enstitüsü Dergisi, Sayı 63, ss.85-93.

Akın, Hale - Kurşunel, Fahri (2010), “TMS-2'ye Göre Stokların Değerlemesinde Özellik Arz Eden Durumlar”, Selçuk Üniversitesi Sosyal Bilimler Meslek Yüksek Okulu Dergisi, Say1 13, ss.311-330.

Arısoy, Kadriye - Tuğay, Osman (2019), "Stok Maliyetlerinin Ulusal ve Uluslararası Mevzuat Çerçevesinde İncelenmesi ve Bir Uygulama”, Ataturk University Journal of Economics \& Administrative Sciences, Sayı 33, Cilt 1, ss.155-179.

Aytaç, Alp - Gücenme Gençoğlu, Ümit (2020), “Maddi Duran Varlıklar ve Amortismanlar Açısından TFRS, BOBİ FRS, KÜMİ FRS Taslağı ve MSUGT'daki Uygulamaların Karşılaştırılması”, Business and Economics Research Journal, Vol 11, No 3, pp.753767.

Boyar, Ender - Güngörmüş, Ali Haydar (2006), “TMS-2 Stoklar Standardında Maliyet Yöntemi ve Bir Uygulama Önerisi”, Marmara Üniversitesi Analiz Dergisi, Cilt 7, Say1 16, ss.83-91.

Gücenme Gençoğlu, Ümit (2020), “Küçük ve Mikro İşletmeler İçin Finansal Raporlama Standardı Taslağı'nın BOBİ FRS ve Vergi Uygulamalarımız ile Karşılaştırılması ve Genel Değerlendirme”, Business and Economics Research Journal, Vol 11, No 1, pp.187-199.

Gökçen, Gürbüz - Öztürk, Erkan - Güleç, Ömer Faruk (2019), "KÜMİ FRS Seti Taslağ1, BOBİ FRS Seti ve Tam Set TMS/TFRS'nin Temel Konular Açısından Karşılaştırılması”, Finans Ekonomi ve Sosyal Araştırmalar Dergisi, Cilt 4, Sayı 3, ss.413-430.

Kamu Gözetimi Muhasebe ve Denetim Standartları Kurumu (2017), Büyük ve Orta Boy İşletmeler İçin Finansal Raporlama Standard1, www.kgk.gov.tr/ (Erişim Tarihi:13.08.2020).

Kamu Gözetimi Muhasebe ve Denetim Standartları Kurumu (2019), Küçük ve Mikro İşletmeler İçin Finansal Raporlama Standardı Taslağı, www.kgk.gov.tr/ (Erişim Tarihi:09.09.2020).

Kamu Gözetimi Muhasebe ve Denetim Standartları Kurumu (2020), Türkiye Muhasebe ve Türkiye Finansal Raporlama Standartları 2020 Seti, www.kgk.gov.tr/ (Erişim Tarihi:22.09.2020).

Kılınç, Yavuz - Badem, Ahmet Cemkut (2020), “Atıl Kapasite, Tam Kapasite ve Kapasite Fazlası Üretim Düzeylerinde TMS-2 Stoklar Standardına Göre Maliyetleme: Bir Örnek Uygulama”, Muhasebe ve Finansman Dergisi, Sayı 87, ss.53-64. 
Kıymetli Şen, İlker - Özbirecikli, Mehmet (2020), "KÜMİ FRS'nin İş Dünyasına Sağlayabileceği Yararlar: BOBİ FRS, TMS/TFRS ve Mevcut Muhasebe Sistemi ile Mukayeseli Bir İnceleme”, World of Accounting Science, Sayı 22, ss.1-19.

Kurtlu, Ayşe ve Gobi, Koray (2020), "Konaklama İșletmelerinde Tamamlanmamış Hizmet Üretim Maliyetlerinin TMS 2 Açısından İncelenmesi”, Journal of Humanities and Tourism Research, Say1 10, ss.313-325.

Marşap, Beyhan - Barış̧̧ı, Atilla (2014), "TMS-2 Stoklar Standardına Göre Dönüştürme Maliyetlerinin Ürün Maliyetlerine Etkisi”, Muhasebe ve Vergi Uygulamaları Dergisi, Cilt 7, Say1 1, ss.1-16.

Selvi, Yakup - Ercan, Melis (2018), “BOBİ FRS Kapsamında Stoklar”, Muhasebe Enstitüsü Dergisi, Cilt 16, Say1 59, ss.47-57.

Taştan, Hakan - Türedi, Ersu - Bayar, Erhan (2020), "Emtia Alımlarında Oluşan Vade Farklarının VUK ve TMS 2 Stoklar Standardı Kapsamında Karşılaştırmalı İncelenmesi ve Muhasebeleştirilmesine Yönelik Bir Uygulama”, Mali Çözüm Dergisi, Say1 159, ss.55-67.

Tuğay, Osman (2013), "Stok Değer Düşüklüklerinin TMS 2 Stoklar Standardına Göre İncelenmesi”, Sosyal Ekonomik Araştırmalar Dergisi, Cilt 13, Sayı 26, ss.207-230.

Vergi Usul Kanunu, 10.01.1961 tarihli ve 10703 sayılı Resmi Gazete, Say1

Yalçın, Selçuk (2019), "Türkiye Finansal Raporlama Standartları, Büyük ve Orta Boy İşletmeler İçin Finansal Raporlama Standardı ve Muhasebe Sistemi Uygulama Genel Tebliğlerinde Stoklar: Muhasebeleştirme, Değerleme, Sunum ve Açıklamalar”, Dumlupınar Üniversitesi Sosyal Bilimler Dergisi, Sayı 60, ss.202-222.

1 Sira Nolu Muhasebe Sistemi Uygulama Genel Tebliği, 26.12.1992 tarihli ve 21447 (Mükerrer ) sayılı Resmi Gazete.

238 seri No’lu Vergi Usul Kanunu Tebliği, 02.03.1995 tarihli ve 22218. Sayılı Resmi Gazete, 